\title{
Colston E. Warne Lecture: Is it Time for Another Round of Consumer Protection? The Lessons of Twentieth-Century U.S. History
}

\section{Citation}

Cohen, Lizabeth. 2010. Colston E. Warne lecture: Is it time for another round of consumer protection? The lessons of twentieth-century U.S. history. The Journal of Consumer Affairs 44(1): 234-246.

\section{Published Version}

doi:10.1111/j.1745-6606.2010.01164.x

\section{Permanent link}

http://nrs.harvard.edu/urn-3:HUL.InstRepos:4322612

\section{Terms of Use}

This article was downloaded from Harvard University's DASH repository, and is made available under the terms and conditions applicable to Other Posted Material, as set forth at http:// nrs.harvard.edu/urn-3:HUL.InstRepos:dash.current.terms-of-use\#LAA

\section{Share Your Story}

The Harvard community has made this article openly available.

Please share how this access benefits you. Submit a story.

\section{Accessibility}


Is It Time for Another Round of Consumer Protection?

The Lessons of Twentieth-Century U.S. History

\author{
By \\ Lizabeth Cohen
}

Colston E. Warne Keynote Lecture

American Council of Consumer Interests (ACCI) Annual Meeting

Milwaukee, Wisconsin

July 28, 2009

To be Published in The Journal of Consumer Affairs,

Spring 2010

Lizabeth Cohen

Howard Mumford Jones Professor of American Studies

Chair, Department of History

Harvard University

201 Robinson Hall

Cambridge, MA 02138

Cohen3@,fas.harvard.edu

(O) 617-495-2504

Assistant Kristina Nies 617-496-4067

(H) 617-489-1417

(FAX) 617-496-3425 


\begin{abstract}
The first year of Barack Obama's presidency has returned consumer issues to center stage, with several contentious struggles over consumer protection. This moment can be viewed as a fourth wave of the twentieth-century consumer movement, and a comparison with the first three waves (during the Progressive Era, the New Deal, and the 1960s1970s) offers instructive insights. In particular, the contemporary battle over the Consumer Financial Protection Agency (CFPA) bears striking similarities to the failed campaign for a Consumer Protection Agency (CPA) in the 1970s.
\end{abstract}


Is It Time for Another Round of Consumer Protection?

The Lessons of Twentieth-Century U.S. History

In the first year of Barack Obama's presidency, whether--and how--to protect consumers has become one of the most contentious issues before the nation, and many of the other hot policy debates, such as revamping health insurance, could be construed as consumer issues as well (Liberto 2009; Dilemmas of Debt 2009; Voice for the Consumer 2009). At the time of this writing, seven months into Obama's term, a commitment to strengthening a weakened Food and Drug Administration (FDA) and Consumer Product Safety Commission (CPSC) has made headlines, and legislation to protect consumers from credit card company abuse has been passed by Congress and signed by the President (Cooper 2009a; Cornish 2009; Ferraro 2009; Leondis 2009; Liptak 2009; Martin and Harris 2009; Moss and Martin 2009; Stephen J. Dubner, Freakonomics Blog, comment posted July 16, 2007; Substantial Complications 2009). Moreover, we are currently witnessing a deadly shoot-out over a proposed Consumer Financial Protection Agency (CFPA), intended to regulate how financial institutions provide a range of products including mortgages, credit cards, and bank accounts (Andrews 2009; Cooper 2009b; Dennis 2009a; Dennis 2009b; Herbert 2009; Labaton 2009; Martin and Story 2009). The sharpshooters are the Obama administration and its liberal Democratic Congressional allies like Barney Frank, on the one hand, and big banks, credit card companies, the U.S. Chamber of Commerce, and many Republican lawmakers on the other. Ben Bernanke, chief of the Federal Reserve, publicly sided against the White House and with the opponents of the CFPA, arguing that a new agency was unnecessary, that the Fed should 
retain responsibility for consumer protection (Americans for Financial Reform; Aversa 2009).

I am a historian of the past, not a predictor of the future. So I cannot anticipate how these contemporary struggles will turn out. What I can do, however, is document what we know about other moments of conflict over protecting consumers and explore what that historical perspective suggests about our current challenges. First, I will present what in my book, A Consumers' Republic: The Politics of Mass Consumption in Postwar America (Cohen 2003), I have identified as three waves of consumer mobilization in the twentieth century: the first wave in the Progressive Era during the early decades of the twentieth century, the second wave from the Great Depression through the 1940s, and the third wave during the 1960s and 1970s. One might, in fact, call the present moment the fourth wave of consumer activism, as a new President has just taken office with a reform agenda that includes a number of consumer-oriented initiatives. Then, I will focus in on a struggle not so very different from the one we are engaged in today over creating the Consumer Financial Protection Agency, the long-and ultimately unsuccessful--battle for a cabinet-level Consumer Protection Agency during the 1970s. Understanding why that effort failed will hopefully provide some useable lessons for today.

First, here is an overview of the three waves of consumer mobilization over the twentieth century (Cohen 2003; Cohen 2008). All three waves coincided with broader periods of reform - whether the Progressive Era of the early twentieth century, the New Deal of the 1930s and 1940s, or the Great Society of the 1960s. In all three periods, it seems, when reformers critiqued the failings of the status quo and sought to establish a more equitable and socially responsible capitalist democracy, they seized on better 
protecting the rights and safety of consumers as a crucial step. Progressives of the early twentieth century considered empowering and protecting consumers as a crucial way of defending the American citizenry from the alarming growth of exploitative corporate monopolies and political corruption. They argued for such legislation as the Pure Food and Drug Act, the Meat Inspection Act, and the anti-trust Federal Trade Commission Act, as well as the importance of regulating decent working conditions if consumer goodsand the laborers who made them--were to be kept safe. A couple decades later, the New Dealers of the 1930s embraced consumer representation and protection as a way of incorporating the public interest into the welfare state that they were expanding to cope with the Great Depression. Further regulation of food, drugs, and banking; the creation of consumer divisions within New Deal agencies; experimentation with consumer cooperatives and education--all became essential dimensions of the New Deal and homefront mobilization during World War II. Finally, another two decades later, an even more robust consumer movement, energized by President Lyndon Johnson's Great Society, established much of the infrastructure for modern consumer protection- the Water Quality Act of 1965, the National Traffic and Motor Vehicle Safety Act of 1966, the Fair Packaging and Labeling Act of 1966, the Consumer Product Safety Act of 1970 (and the establishment of the Commission in 1972), and the Equal Credit Opportunity Act of 1974, to name only a few. It should be clear that these three waves of activism were not moments of political revolution, but rather were liberal recalibrations of the economic and political balance of power between "the little guy and gal" and big corporate interests. In these reform moments, championing consumers became a way of 
arguing for the public good, based upon the assumption that consumers in the capitalist economy had rights and deserved protection much like citizens did in a democratic polity. Interestingly, in all three of these twentieth-century activist moments, women made up many of the masterminds and often the shock troops of the consumer movement. This happened for a variety of reasons. They were usually the chief family purchasers and budget watchers. They were commonly members of organizations and associations, most of them exclusively female, that could be mobilized for the cause, such as the General Federation of Women's Clubs, the American Association of University Women, and during the Great Depression, Housewives Leagues in cities all over the country, and women's auxiliaries allied with the burgeoning labor unions. And consumer activism had a kind of legitimacy for female social reformers that more traditional political activity often did not, an extension of the "municipal housekeeper" role that nonvoting Progressive Era women had explicitly invoked to justify their intervention into the civic realm. What female activists often called "ethical consumption" was a strategy of selective buying to achieve social and political, as well as economic, ends. Activities included boycotts of goods feared to be injurious or unsanitary for consumers, boycotts of manufacturers and retailers who forced women and sometimes children to work under unsafe and exploitative conditions, and boycotts of products like meat with prices deemed too high for the average family budget. They also mobilized to advocate for stricter drug, food and other product protections and to give a voice to consumers in all the corridors of government.

In all three waves of the consumer movement, moreover, another social group frequently excluded from traditional politics became activists in the realm of 
consumption: African Americans. In the Progressive Era, they protested the imposition of Jim Crow laws with consumer boycotts on trolley cars and support for black-owned businesses. Booker T. Washington launched a formal drive for a separate black economy with the formation of the National Negro Business League in 1900; by the 1920s, Marcus Garvey would further promote that strategy through his Universal Negro Improvement Association. In the 1930s, African Americans mounted “Don't Buy Where You Can't Work" campaigns in all major cities of the United States, which were boycotts of retailers and utility companies who readily took black consumers' money but refused to employ them in decent jobs, treated them disrespectfully as customers, and overcharged them for goods, services and credit. Depression-era African Americans also experimented with consumer cooperatives; the influential civil rights leader Ella Baker began her political career, in fact, working for the Young Negroes' Cooperative League in Harlem. During World War II, black consumers protested discrimination in how the Office of Price Administration enforced price and rent controls in their neighborhoods-less stringently and less fairly. And in the 1960s, blacks made good use of provisions in the Great Society programs aimed at helping what became known as "the low-income consumer," they agitated through the National Welfare Rights Organization for equal access to credit, and when all else failed, they expressed rage at their exclusion from the consumer society by looting white-owned stores in their neighborhoods during the urban riots that flared over the decade. In many ways and in many places, consumer activism became inextricably intertwined with the civil rights struggle. It played a key role in the battle for access to public accommodations like movie theaters, beaches, and bowling alleys in the North during the 1940s and 1950s; in the Montgomery Bus Boycott of 1955; in the sit-ins at 
Southern lunch counters in the early 1960s; and in the well executed boycotts of white merchants throughout the 1960s and throughout the South from downtown Birmingham to small towns in the Mississippi Delta. For decades, direct action at the point of consumption was a valuable weapon in the arsenal of black mobilization for full civil rights.

The era of greatest activism and achievement for all consumers was the 1960s and 1970s, the heyday of consumer activism. Its origins were multiple, beginning in the 1950s with Congressional investigations into flammable pajamas, pesticides, and - a bit later--the drug thalidomide, followed by John F. Kennedy's campaign promise to be a lobbyist for the consumer and then delivery of a "Consumer Bill of Rights" in 1962 (with its rights to safety, to be informed and to be heard), which was soon reinforced by his establishment of a Consumer Advisory Council and the appointment of a special assistant to the president for consumer affairs, Esther Peterson. In 1965, Ralph Nader notoriously attacked the "designed-in dangers" of the Corvair and with the $\$ 450,000$ settlement he got from General Motors for its illegal spying on him, he launched his impressive infrastructure of public interest organizations ranging from the Center for the Study of Responsive Law to the state PIRGs. More generally, the postwar growth in affluence encouraged Americans to consume more, but also to have higher expectations for access, quality and dependability of material goods.

This third wave of the consumer movement succeeded on two levels. On the first level, it passed landmark legislation to protect consumers better in the marketplace. I just mentioned a few of those new laws; there were many more. On the second level, it invigorated federal regulatory authority in the consumer interest, dramatically increasing 
the amount of economic and particularly social regulation on behalf of ordinary Americans with new agencies such as the Environmental Protection Agency (EPA), the Occupational Safety and Health Administration (OSHA), and the Consumer Product Safety Commission (CPSC). Some analysts estimate that between 1970 and 1975, social regulation rose by more than $200 \%$. Moreover, the growing responsiveness of courts to product liability suits--their greater willingness to hold manufacturers liable for any malfunctioning and to compensate injured parties accordingly—also strengthened government action on behalf of consumers. What the third-wave consumer movement did not manage to pull off, however, was a third level: to institutionalize a permanent voice for consumers in government. This goal became the "impossible dream" of dedicated consumer activists in the 1960s and 1970s.

The showdown moment for this third-level of the third-wave consumer movement came over the prolonged — and ultimately failed — pursuit of an independent, cabinetlevel Consumer Protection Agency (CPA), an effort that Ralph Nader and many other consumer activists and organizations threw themselves into as the best way to ensure that the consumer interest would be considered in every federal legislative, executive, and judicial policy decision. Because that struggle shares many similarities with today's conflict over the Consumer Financial Protection Agency (CFPA), it bears close examination. The battle for a CPA-like agency began in the late 1950s, continued through the 1960s, and intensified in the 1970s, until it was definitively defeated in 1978. As an early champion of the proposed agency, Senator Warren Magnuson, put it, a "fighting pike was needed in the carp pond" (Pertschuk 2001). Although at first, in the 1960s, Nader dismissed the idea of a new government body as just one more regulatory 
agency to be captured by business, he reversed himself by the 1970s and devoted his full energies to securing the CPA, so crucial did he consider it to leveling the playing field between consumers and corporate America and advancing the consumerist agenda. At the height of the struggle, he led a Committee for the Consumer Protection Bill backed by over two hundred consumer groups, labor unions, and other supporters (Cohen 2003, 361-3; Waterhouse 2009, 185-236; Glickman 2009, 275-302).

From 1970 to 1975, during the Presidencies of Richard Nixon and Gerald Ford, the CPA almost made it out of Congress on several occasions but was kept in check by presidential opposition and the growing effectiveness of the business lobby. This was true, despite clear evidence that the measure had wide support among the public. In 1970, it passed the Senate 74 to 4 but not the House. In 1971-72, it passed the House 344 to 44, but died from a Senate filibuster. In 1974 it again passed the House, this time by less of a margin (293 to 94), and was again blocked by a Senate filibuster. In 1975, it passed both houses, but died in conference committee when President Gerald Ford announced he would veto it and there was no $2 / 3$ vote in the House to override his veto. Finally, when Jimmy Carter moved into the White House, having campaigned on a pro-consumer platform, having reappointed Esther Peterson as his consumer adviser, and having vowed to push through the CPA, hopes rose that now, at last, the CPA would become the law of the land. Instead, the bill went down to defeat in 1978 and would never be resuscitateduntil the much narrower proposal for a Consumer Financial Protection Agency surfaced recently.

So what happened? What happened was what a co-sponsor of the bill, Congressmen Benjamin Rosenthal of New York, considered "the most intense lobbying 
I've ever seen against any bill" (Enemies Endanger 1977). Between 1970 and 1978 corporate America mobilized at a whole new scale and pace from its standard, businessas-usual, self-advertisement of the postwar era. Focused on the CPA as the line-in-thesand that they had to defend against a headstrong and threatening consumer movement, business groups marched into battle. Longstanding organizations like the U.S. Chamber of Commerce, the National Association of Manufacturers, the National Federation of Independent Business, and the Grocery Manufactures Association, were joined by the newer Business Roundtable, founded in 1972 to unite the CEO's of leading corporations, and a specially formed Consumer Issues Working Group, which by 1978 had more than 400 corporate and trade association members. For American business leaders, the CPAto quote a few spokesmen--was a "Trojan Horse threat to American business," "the most serious threat to free enterprise and orderly government ever to be proposed in Congress," and an insulting attack on the "honesty and responsibility of American business" (Crisis in Credibility n.d.; Glickman 2009, 290). More specifically, NAM condemned the CPA as creating "a tax-supported consumer activist group within the government to engage in vital rule-making and participate in the adjudicatory proceedings of the U.S. government with unprecedented investigatory powers over the private sector and the rest of government" (Marable 1974). Already burdened by what business groups considered excessive regulation — estimated by the Business Roundtable to be costing business some $\$ 2$ billion a year by 1979 — they were determined not to tolerate the mother of all regulation, the CPA. The EPA, OSHA, and the CPSC were bad enough. 
Beyond reminding us that business once before fought militantly against a regulatory innovation that aimed to inspect all government policies from the vantage of what was best for consumers, revisiting the CPA battle is instructive for exposing the strategy that the business lobby employed to make its case. Addressing both Congress and the American public through advertising and public relations campaigns, business organizations developed a three-pronged argument--and spent millions to deliver it. First, they insisted that free market competition provided the greatest protection to consumers, since, in the words of President Ford to the delegates of the 1975 annual meeting of the Chamber of Commerce, "the survival of business is directly dependent on its ability to provide the largest number of buyers with goods of high quality, utility and safety at attractive prices" (Ford 1975). And because consumers had choices in the free market, they could pursue their interests freely and democratically. Second, business argued that the CPA would add another level of bureaucracy to what was already a bloated, overregulating government. "The national nanny," "smother love," an emasculating threat to good old American rugged individualism: with incendiary language like this, business groups charged that this agency dangerously increased the stranglehold of government, and did so in a way that insulted the intelligence of ordinary Americans. Ex-governor of California Ronald Reagan attacked the CPA in 1975 in op-ed pieces and radio commentaries as "Big Brother" "promoting the notion that people are too dumb to buy a box of corn flakes without being cheated....The professional consumerists are, in reality, elitists who think they know better than you do what's good for you" (Reagan 1975). Business, helped by friends like Reagan, sought to awaken populist, anti-government fears that were never far beneath the surface in American life. 
The third prong of the attack aimed to reorient the consumer interest away from issues of protection, quality, safety and access toward prices. More government bureaucracy would be wasteful spending that ultimately would be passed on to the consumer and added to the cost of goods. It would not be long until Ronald Reagan's election as President in 1980 would reinforce these arguments. When he asked Americans in 1980 and again in 1984 to consider, "Are you better off now than you were four years ago?" he was defining their well-being and consumer interest in purely economic terms. Virginia Knauer, Reagan's director of the U.S. Office of Consumer Affairs, was even more explicit. "There is a high cost to be paid for consumer protection....When businesses are allowed to regulate themselves, competition will ensure that savings will trickle down to consumers" (Hinds 1982). The key point here is that not only did corporate America successfully vanquish the Consumer Protection Agency, it reshaped the public discourse around consumers and the consumer interest in ways that laid the groundwork for the three decades of market-oriented, neo-liberal policies that would follow.

The parallels between the struggle over the CPA in the 1970s and the CFPA today should be clear. Just as Nader orchestrated a campaign, led by the Committee for the Consumer Protection Bill, to make the CPA law, so today a broad coalition of two hundred consumer, labor, and civil rights organizations has allied to persuade lawmakers and to mobilize grassroots support, acting under the umbrella of the Americans for Financial Reform, which boasts its own website, OurFinancialSecurity.org. Business's response to the proposal also bears similarities to its attack on the CPA in the 1970s. As the Washington Post reported, financial and business critics of the CFPA testified to the 
House Financial Services Committee on July 15, 2009 that "a new agency would add another layer of government regulation, increase costs, stifle innovation and curtail choices for consumers" (Dennis 2009a). The banking industry, which claims it stands to lose billions of dollars if the CFPA is enacted, is "really dumfounded by the scope of this agency," according to the President of the American Bankers Association. "It's not like the current regulators don't have all the authority they need. You don't have to blow up the system" (Martin and Story 2009). A coalition of the American Financial Services Association, the American Bankers Association, the National Auto Dealers Association, the U.S. Chamber of Commerce, the Mortgage Bankers Association, and other groups opposed to the CFPA are strategizing together about how to mount their campaign, interviewing public relations firms in search of schemes for advertising and grassroots outreach. They are reportedly considering a television campaign similar to the "Harry and Louise" ads that helped undermine Bill Clinton's health care proposals in the early 1990s. According to Scott Talbott, Senior Vice-President of Government Affairs at the Financial Services Roundtable, which represents the nation's largest financial firms, "We're for protecting consumers. The question is, what's the best way to do it?" (Dennis 2009b). Sound familiar?

Many lessons may be learned from the defeat of the consumer movement's centerpiece legislation more than thirty years ago, including that it is difficult for consumer groups to battle business with its seemingly bottomless pockets. But I would venture that the most critical lesson we can learn is the importance of controlling the message, not just resting the case on the merits of the proposal. In researching this essay, I watched a video on YouTube of Elizabeth Warren (2009), a professor at Harvard Law 
School who is chairing the Congressional Oversight Panel for the banking bailout, formally known as the Troubled Assets Relief Program or TARP. Warren came up with the idea for the CFPA and has been pushing hard for it. In the video she explains the proposed new Consumer Financial Protection Agency in very simple, straight-forward, compelling terms to the public. Clearly, she understands that this is a battle for the hearts and minds of Americans. But as business gears up for war, determined that the CFPA is another line in the sand that will not be crossed, the fight promises to be nasty and the outcome uncertain. Bernanke's recent dismissal of the Obama administration's proposed agency is a bad sign.

More broadly, how does this history of consumer mobilization over the last century speak to my initial question, "Is It Time for Another Round of Consumer Protection?" Clearly another round of mobilization is underway. The uncertainty is how successful it will be. To those who would argue that an economic downturn is not the right time to mobilize consumers, I would point to the paradox of this history: consumers are most easily politicized in tough economic times, when they are feeling economically insecure and worried about their vulnerabilities as producers and consumers. We saw that in the Depression Thirties and again in the inflationary late Sixties and Seventies. On the other hand, when faced with this new assertiveness by consumers and their organizations in the depths of a recession or depression, big business can play the card of arguing that more regulation will raise the cost of goods and services and hurt the recovery. We see that positioning in business's response to the CFPA, and in the debate over reforming health insurance as well. 
A second observation in comparing these historical consumer movements to today relates to a change in the tactics of political mobilization over time. Whereas public support for consumer protection has remained crucial to its success over the last century, its structure has changed from citizen organizations with organic connections to the grassroots to professional lobbyists whose tentacles reach the grassroots only through carefully orchestrated internet and direct mail campaigns. This shift from rank-and-file activism to mailing list memberships has affected all political organizing over the course of the twentieth century, most dramatically the political parties themselves. In the consumer realm, images of parading mothers pushing babies in carriages to protest impure milk in the 1930s or women boycotters marching outside supermarkets waving home-made placards complaining about the cost of meat in the 1950s or hundreds of consumer activists demonstrating in front of the U.S. Chamber of Commerce Headquarters in Washington to urge acceptance of the CPA in 1977 seem quaint, and unimaginable, today. Instead, supporters are recruited through mail, email and websites like moveon.org and OurFinancialSecurity.org, as well as through the thoroughlysegmented mass media. Politically aligned talk radio hosts and television commentators galvanize like-minded audiences. The CFPA sounds like one entity when discussed by Rachel Maddow or Keith Olbermann on MSNBC, quite another when described by Bill O’Reilly on Fox News or Lou Dobbs on CNN.

Clearly, public pressure still matters to win reforms, but advocates face new and complex pressures with today's politics. The explosion of special interest lobbying since the 1960s has not only meant more influence peddling by business; it has changed the nature of popular political mobilization as well. A lesson from history still applicable 
despite this shift in political organizing is the importance of reaching beyond white males to the social groups who have repeatedly responded to consumer issues-particularly women and African Americans. Today one should add Latinos and other recent immigrant groups. With the CFPA's orientation toward financial products, it may be tempting for organizers to fall into the trap of targeting the stereotypical male consumer, and white men at that. They need to remind themselves that mortgages, credit cards, bank accounts and other financial instruments affect everyone and that they must reach out broadly. The 2008 presidential election proved to politicians that minorities vote, and most financial businesses certainly know that their customer base is diverse.

This recommendation to mount a broad-based appeal on behalf of the CFPA is part of a larger lesson to be gained from a century of consumer organizing: the necessity of attracting as wide a swath of Americans as possible to campaigns for consumer rights. The more Americans who feel they will benefit, the more popular and successful the campaign. Health care reform, in fact, may get killed off by opponents who are trying to divide consumers between Americans who have secure jobs and health insurance and do not want to pay more to insure others, on the one side, and Americans who have no insurance or are either unemployed or fear the prospect of losing their jobs on the other. The challenge before all of us who care about the rights and vulnerabilities of consumers and are committed to creating as equitable and democratic an economic marketplace as is possible within our capitalist system is to revitalize the language and politics of the New Deal where caring about consumers was understood as a core part of protecting the common good of the nation. As Roosevelt explained when he justified the new consumer offices in his New Deal agencies and defended pro-consumer legislation, these efforts 
reflected "a new principle in government"- that consumers have the right "to have their interests represented in the formulation of government policy....Never before ha[ve] the particular problems of consumers been so thoroughly and unequivocally accepted as the direct responsibility of government. The willingness to fulfill that responsibility...[is], in essence, an extension and amplification of the meaning and content of democratic government" (Roosevelt 1938, 57). Likewise, when the young crusader Ralph Nader chose to call his activist network the "public citizen," he too was linking advocacy for consumers to the collective good of citizens. President Obama, here's some advice: take some pointers from Franklin Roosevelt and Ralph Nader and make it crystal clear that consumers are not simply another special interest group to be carefully balanced against business interests, but rather are the unhushable voice of the people in this capitalist, democratic nation of the United States. 


\section{REFERENCES}

Americans for Financial Reform. U.S. Chamber, Big Banks Continue Attack on America’s Economic Recovery. Americans for Financial Reform. http://www.ourfinancialsecurity.org.

Andrews, Edmund L. 2009. Banks Balk at Agency Meant to Aid Consumers. New York Times, July 1.

Aversa, Jeannine. 2009. Bernanke Balks at Plan for Consumer Protection Agency. Boston Globe, July 23.

Cohen, Lizabeth. 2003. A Consumers' Republic: The Politics of Mass Consumption in Postwar America. New York: Alfred A. Knopf.

-.2008. Making a New Deal: Industrial Workers in Chicago, 1919-1939. 2nd ed. New York: Cambridge University Press. (Orig. pub. 1990.)

Cooper, Helene. 2009a. Obama Chooses an Educator to Lead a Criticized Safety Agency. New York Times, May 6.

_. 2009b. Obama Pushes Financial Regulatory Overhaul. New York Times, June 21. Cornish, Audie. 2009. Senate Passes Credit Card Overhaul Bill. Morning Edition. Washington, DC: National Public Radio, May 20.

"The Crisis in Credibility: Theme of a Marketing Conference to Which You Are Invited." n.d. National Association of Manufacturers Papers (NAM). Box 222. Folder "NAM sponsored conferences/symposiums/workshops, etc." Quoted in Waterhouse, 2009, 191-2.

Dennis, Brady. 2009a. Consumer Groups Praise Idea of Financial Protection Agency. Washington Post, July 17. 
- 2009b. Industry Takes Aim at Plan to Create Financial Protection Agency.

Washington Post, July 7.

Dilemmas of Debt. 2009. New York Times Magazine, May 17.

Enemies Endanger Consumer Agency. 1977. Washington Star, June 19.

Ferraro, Thomas. 2009. US Senate Confirms New Consumer Safety Chief. Reuters, June 19.

Ford, Gerald. 1975. Remarks at the Annual Meeting of the Chamber of Commerce of the United States. April 28. The American Presidency Project. http://www.presidency.ucsb.edu. Quoted in Waterhouse, 2009, 211.

Freakonomics Blog, http://freakonomics.blogs.nytimes.com/.

Glickman, Lawrence B. 2009. Buying Power: A History of Consumer Activism in America. Chicago: University of Chicago Press.

Herbert, Bob. 2009. “Chutzpah On Steriods.” New York Times, July 14.

Hinds, Michael deCourcy. 1982. Laissez-Faire Consumerism. New York Times, August 21.

Labaton, Stephen. 2009. Some Lawmakers Question Expanded Reach for the Fed. New York Times, June 17.

Leondis, Alexis. 2009. Credit-Card Consumer Protection Law May Reduce Purchasing Power. Bloomberg.com, May 22.

Liberto, Jennifer. 2009. Consumers Gain Clout in Washington. CNNMoney.com, May 29. Liptak, Adam. 2009. No Legal Shield in Drug Labeling, Justices Rule. New York Times, March 5. 
Marable, D.E. 1974. ABDCEFG nears final verdict. NAM Reports, Vol. 9, no.30, August 5. NAM Papers. Box 213. Quoted in Waterhouse, 2009, 196.

Martin, Andrew and Gardiner Harris. 2009. Outbreaks and Recalls Put Worry on the Table. New York Times, May 11.

Martin, Andrew and Louise Story. 2009. Tough or Timid? Banks Brace for Fight Over an Agency Meant to Bolster Consumer Protection. New York Times, June 18.

Moss, Michael and Andrew Martin. 2009. Food Safety Problems Slip Past Private Inspectors. New York Times, March 6.

Pertschuk, Michael. 2001. Personal interview, November 13, Boston, Mass.

Reagan, Ronald. 1975. Consumerists Out: Will Return. Manhattan Mercury, January 26. Quoted in Glickman, 2009, 292.

Roosevelt, Franklin Delano. 1938. The Advance of Recovery and Reform, 1934. Vol. 3 of The Public Papers and Addresses of Franklin D. Roosevelt. New York: Random House.

Substantial Complications. 2009. New York Times, May 11.

A Voice for the Consumer. 2009. New York Times, January 4.

Warren, Elizabeth. 2009. "Professor Elizabeth Warren Speaks About the Consumer Financial Protection Agency.” YouTube. http://www.youtube.com/watch?v=1Yd08e5Cjvs.

Waterhouse, Benjamin Cooper. 2009. A Lobby for Capital: Organized Business and the Pursuit of Pro-Market Politics, 1967-1986. Ph.D. diss., Harvard University. 